\title{
Women with Blood Hypertension: A Dialogical Reflection
}

\section{Garcia-Reza Cleotilde ${ }^{1}$, Sosa-García Betsy Corina ${ }^{2}$, Silvia Teresa Carvalho de Araujo ${ }^{3}$, Diaz-Oviedo Araceli4, Gloria Solano Solano ${ }^{5}$}

\author{
${ }^{1}$ Departament of Nursing in Investigation, Autonomous University of State of Mexico, Toluca, Mexico \\ ${ }^{2}$ Departament of Nutrition, Autonomous University of State of México, Toluca, Mexico \\ ${ }^{3}$ Departament of Nursing in Investigation, University Federal of Rio de Janeiro, Rio de Janeiro, Brasil \\ ${ }^{4}$ Departament of Investigation Nursing, Autonomous University of San Luis Potosí, San Luis Potosí, Mexico \\ ${ }^{5}$ Department of Nursing, Autonomous University of Hidalgo, Pachuca, Mexico \\ Email:cgar0506@yahoo.com.mx,cgar0506@yahoo.com
}

How to cite this paper: Cleotilde, G.-R., Corina, S.-G.B., de Araujo, S.T.C., Araceli, D.-O. and Solano, G.S. (2018) Women with Blood Hypertension: A Dialogical Reflection. Open Journal of Nursing, 8, 188-195. https://doi.org/10.4236/ojn.2018.83016

Received: January 27, 2018

Accepted: March 12, 2018

Published: March 15, 2018

Copyright $\odot 2018$ by authors and Scientific Research Publishing Inc. This work is licensed under the Creative Commons Attribution International License (CC BY 4.0).

http://creativecommons.org/licenses/by/4.0/

\begin{abstract}
The article reflects on the "philosophy of dialogue" of Martín Buber for the analysis of the relationship of women who live with arterial hypertension. With the theoretical proposal of Buber, considering the social context from the world view of the disease, this leads to relationships of suffering and anguish, but with dialogue among the people who live with this disease it is observed in specific cases of chronic disease. Likewise, the panorama of the problem is the interaction between the social being and the disease, in order to generate a dialogue between the disease and the women who live daily this condition.
\end{abstract}

\section{Keywords}

Dialogic, Health, Arterial Hypertension, Women, Care

\section{Introduction}

Coexistence with women living with arterial hypertension [1]; from reality, it starts with dialogue [2] between illness and care of life in this new life-health process, from where gender dissertations are encouraged in the face of social reciprocity, in relation to the characteristic way of living with high blood pressure, to understand what this life condition carries with it.

Dialogue at present has no echo, since it is diverted as a lost focus of reality to insert itself in a world of technology away from the subject of care [3], however, the need for dialogue exists that implies a call that addresses the word to an an- 
swer that consists of taking responsibility for the word, which is pronounced and directed towards dialogue in care relationships from the philosophical perspective of nursing [4].

It is evident that it is not only a communicative strategy, but also, a construct that converges and concentrates the proper care of women with arterial hypertension, showing a social structure possessed in the care of the self and you [5], as a content of dialogical care from the position of the disease before the silence granted by the stealthy murderer, predominantly in women [6].

This breaks the paradigm of communication with the reciprocity of change, in each of the social actors, which involves the characteristics of an act of dialogue with the other, that is why dialogue is a principle of relationship and mutual recognition of the people involved in a process of health and disease, this can be, the doctor, family, friends and contexts where sick or healthy social beings are [7] [8].

Dialogue is involved in these processes, as a process of meeting between open thinking and the environment that surrounds the disease, ranging from silence, when there is no dialogue of agreement and disagreement, to the nursing interventions where the intersubjective relationship of dialogicity, based on the needs of interaction with human coexistence with others and with the care environment [9] [10].

To deepen the relationships between the sensitive and intangible world of arterial hypertension; between the opinions and the scientific and philosophical knowledge, then [11] [12] becomes its epistemological framework of care, which takes possession of self-determination in a dialogue with the other, to overcome fear to the death of the silent killer.

\section{Objective}

To analyze the dialogical meaning of being hypertensive in women of an exercise program.

\section{Method}

The project was developed in women living with arterial hypertension, enrolled in the Exercise Program of a municipality of the State of Mexico. 36 women with hypertension participated, in relation to the calculation of the sample, it was until obtaining the theoretical saturation of the data. The diagnosis was confirmed by the health center doctor. Over 18 years old, with confirmed diagnosis, without communication problems. The data were collected through the semi-structured interview, whose purpose was to reflect the dialogue between women living with arterial hypertension and the disease. A previous appointment was requested to inform about the objective of the investigation and obtain the signature of the informed consent.

An office was held to request authorization to conduct the interviews, in this way gathering information based on the free speech of the women and finally 
reporting and interpreting what was described in the findings.

Authorization was also requested to record the interviews, ensuring the confidentiality of the stories. Open interviews were held between September 2016 and April 2017. All were recorded, transcribed in full by assigning a code to each participant, represent the interview. Two researchers conducted the interviews in a health center room. Open interviews were made on average from 45 to 60 minutes, recorded in audio, with a question that guided the investigation: What do you feel when your blood pressure rises? What do you think?

The process was to analyze them from the reading to reflect the dialogic of the participants with the technique of the content analysis of [13] from where the central category is detached and transcribed in the Microsoft Word program.

According to the General Health Law, in articles 13 and 14, before starting the interviews, the subjects of the study were duly informed about the objectives and development of the investigation to request free and informed consent, ensuring anonymity of information [14].

\section{Results and Discussion}

36 women were interviewed, with an average age of $58 \pm 7$ years old, 22 widows, 14 married, 28 Catholic and another eight, with incomplete primary schooling 26 , technical career six and four with truncated university studies.

On the other hand, women perceive the disease as something that continually precipitates them in their everyday doing and being, which suddenly shakes them up, affecting the dialogical relationship of their life to the point of losing interest in life, such as expressed in the dialogue process; when her heart falls into a glass of cold water.

... The pressure goes up, uh! My heart falls into a glass of cold water, it freezes my day, and that's when the mood and discouragement come, but I get up, that is, although to tell the truth I can't get up many times, fear takes over inside me and it leaves me cold, that feeling of cold inside but I tell him from my heart "What the heck do you want?!" And he doesn't answer, I think maybe, he is scared as it happens to me...

It is clear that these women who live with this disease need to enter into dialogue with their subjective and objective being, that means facing fear, anguish and discouragement, underlying the difficulties for the control of blood pressure, especially when there is discouragement related with the symptoms and the disease, since it produces a sensation of constant discussion to regain health, but it is not abandoned, on the contrary, that discouragement is confronted with an encouraging spirit, and they cry to eliminate fear, uncertainty, as It shows in the following story:

... You can't live like this, definitely not, without dialogue, without words, that happens with my illness, it seems that there is no relationship with my body. When it's altered, I ask myself: What is happening, what is this? There is a being inside me who doesn't know me, who attacks me until I fall, until I even think that he is a stranger to my body and fear comes. It increases every time, and then 


\section{I scream but he doesn't listen!...}

This represents a clash between the feelings of women and the expression of the disease that is how the egalitarian dialogue is born [12] between the environments that encourage it and those that hold it back from day to day. It is when the relationship between an agreement and the conflict of the social being, to differentiate the argument from the force and the rejection of the symptoms of the disease that narrow the relationship between silence and voices [15], which in reality sustains that dialogical spin of illness, when these women are the protagonists of these transformations in their daily life, to get to contend and understand the disease, until they reach their control as soon as possible.

With this idea, the discourses produced by the disease are summarized in sentences of anguish about what the body and soul of these women living with high blood pressure really feel.

...The disease is present and that's it, it is an entity, but it seems like a treasure, that something that can't be looked at, something between what exists and it can't be explained, it's only felt, and it makes you distrust. There is no confidence in what will happen tomorrow, it's totally unknown, and you ask him what happens and he doesn't answer, he just crushes you and that's it...

It is possible a vindication of the disease and the social being that lives the disease through a dialogue between the voice of the social actors since they are the ones who interact between different cultures in a dialogical way [16] to transform the practices to create dialogical spaces of development based on communication and the health problem, when it manifests itself [17].

The importance of the presence of the disease in everyday life as a health condition that goes beyond their economic, social, racial or cultural situation, seems to be an entity that contends something unexpected, capable of stimulating the thought of distrust, but also to the concrete action of facilitating the dialogue between what you feel and what you think, it is a scenario for the construction of responsibility as key points for dialogue in the discourses of these women when one informs the relationship between a sense of dialogue as a center of debate, and the challenge to achieve confidence in that social being overwhelmed by the disease, as shown in the dialogues:

... One minute, an eternal rest, it's an oversight that leads you to death, that's why one minute is an eternal rest, that means, there is no communication, nothing, I don't speak about my problem, but it drowns my body, even though it speaks to me I do not hear it...

These evidences lead to different knowledge of these women, when they build them with the lifestyle of the disease, with the help of experiences through the social world [10] when the body speaks and they do not listen to it, it takes only a minute for an eternal rest, that story is a sense of death, with that dialogic that is inside and confronts a position to their actions of relationship and interaction in their daily life. Buber (1982) [5] situates dialogue as the heart of communication and human existence with other people, it is a way to promote the development of oneself with the knowledge of the real world that lives in its social en- 
vironment [18].

The contribution of this philosopher is the dialogical principle as the only human possibility of access to being. His philosophy of dialogue is key to demystifying the idea of self-sufficiency and has influenced to understand the encounter from the perspective of care, that perspective considers the actors with a force to preserve health and resignify their state of health [5] [17].

The position of dialogue exists, but in these stories it seems to discover something new, before this disease, when it becomes part of your body, the dialogue becomes a necessity, because it is always next to the being that bears a disease that suffocates, and makes lose the balance of the meaning of life.

... Sometimes I think that if I speak out, I tell my illness what I feel. It's better that way, that illness understands me sometimes, sometimes it doesn't listen, but I do hear when it bursts with courage, and it goes up until I suffocate, I lose my balance, the meaning of life. I speak to her, one and a thousand times but she is always present when I least expect it, night, day, sun, rain, early morning, happy or sad; I do not understand it, I don't understand that talk about this killer disease, they say, that it is silent...

This position of dialogue is constant as the beating of the sick heart by arterial hypertension, the relationship with the body arises, the symptom knows what the body feels, until recovering the senses, hearing, sight. This is only possible through dialogue to live the equality of differences and its dialectical transformation. It never ends, when the illness suffocates, it happens when the being is sad or happy, the symptom is present, under this paradigm the change is reflected from the physical towards the social and humanistic of those who live with this disease [9] [19].

The interest in maintaining a state of health, is born of a certain ability to safeguard health or in try to control or eliminate the discomfort that is present, even with contemplations to establish a dialogue of agreements between those who attack your body, to understand more deeply how to achieve control of the disease as shown in the dialogues:

... Sometimes I want to drown the disease, I don't pay attention to it, but it beats me, then I speak in chinga with her, that's it, I get angry, does it make a difference? At the end of the day she answers me, I talk to her and she talks to me, she starts to go down, to go down, until it's under control. I say: "At last this damn fight let me alone"...

The human being constantly changes, before a milestone of disease, aware of its evolution and of the interaction for the understanding of the disease, with its eternal surprise that every day will be different, in each day, a new awakening to more alarming sensations, like those that are never able to define but that require to be dialogued, to reach the human essence through dialogue, it is possible to conceive a fatal outcome when losing comfort and well-being [19] [20].

As fatal as the fear for life, that makes them to be alert, and does not wait for the dialogue, it is present from the reasoning Buber, (1982) [5] shows that the existential relationship from the stage of coexistence, as part of the experiences 
that they live with the disease, they perceive their vision of the world with high blood pressure, and often to minimize suffering, fear and sadness, it is at this moment when dialogue is irreplaceable [15], without it, the outcome is fatal, almost mortal, like this group of women refers to it [17] [20] [21].

It is emphasized that the main limitation of this study are the methods to advise women with this health problem, since they may have an overestimation relative to the interview, another limitation is the need for greater production of related articles with this issue, for this reason, it is suggested to expand the research between this philosophy and arterial hypertension to understand the findings with this reference used by other researchers evidenced in the scientific production of nursing.

\section{Final Considerations}

From the reflections, the dialogical communication is highlighted: "When my heart falls in a glass of water...”. During the illness of these women who live with arterial hypertension, in this way the nursing professionals can deduce that they are holistic beings, considering their way of thinking and feeling to minimize their suffering and anguish. In this sense, the dialogical is irreplaceable as a relevant feature in the relationships body disease, dialogue is crucial. Therefore, by recognizing the abilities to establish dialogic communication, you can understand its vision of the world before the disease.

Therefore, Buber's philosophy represents a potential that contributes to the production of new knowledge for the nursing care, as well as being a reference to generate knowledge that fosters the development of a care, rational, dialogical and humanistic based on the needs of each person with a health situation under a paradigm that guides the health actions derived from nursing assessment in the care process.

In this way the results of this research focus on the process of unfinished dialogues, between the disease and the body of those who live with this disease, generating a list of internal and external agreements to share those dialogues in order to control the disease when it is required, as a strategy to be considered by the nursing professional in their daily care.

\section{References}

[1] Ortiz Marrón, H., Vaamonde Martín, R., Zorrilla Torrás, B., Arrieta Blanco, F., Casado López, M. and Medrano Albero, M. (2011) Prevalencia, grado de control y tratamiento de la hipertensión arterial en la población de 30 a 74 años de la Comunidad de Madrid. Estudio PREDIMERC. Revista Española de Salud Pública, 85, 329-338. http://www.redalyc.org/comocitar.oa?id=17019926002

[2] Vázquez Verdera, V. (2013) Martin Buber y sus aportaciones a la manera actual de entender la educación para el cuidado. Educació i Història: Revista d'História de l'Educació, 21, 143-158.

[3] Baggio, M. (2006) O significado de cuidado para profissionais da equipe de enfermagem. Revista Eletrônica de Enfermagem, 8, 9-16.

https://doi.org/10.5216/ree.v8i1.949 
[4] Zaragoza, F. and Bailey, C. (2017) Critical Review of the Evolving Essence of the Science of Nursing: Complexity Integration Nursing Theory (CINT) E-Book. International Journal of Nursing \& Clinical Practices, 4, 228. https://doi.org/10.15344/2394-4978/2017/228

[5] Buber, M. (1982) Do diálogo e do dialógico. Perspectiva, São Paulo.

[6] Rojas, M., Rosales, Y., Guerrero, N., Morillo, J., Añez, R., Bermúdez, V. and Rojas, J. (2016) Comportamiento epidemiológico de la hipertensión arterial en individuos adultos del municipio San Cristóbal del estado Táchira-Venezuela. Revista Latinoamericana de Hipertensión, 11, 1-11.

[7] Diego, S. and Maria da Graça Oliveira, C. (2008) O elemento dialógico no cuidado de enfermagem: um ensaio com base em Martin Buber. Escola Anna Nery Revista de Enfermagem, 12, 544-548. https://doi.org/10.1590/S1414-81452008000300022

[8] Higuera-Dagovett, E., Rojas-Gil, M. and Garzón de Laverde, D. (2015) Experiencia de hipertensión arterial en la relación paciente, familia y contexto de ayuda. Revista de Salud Pública, 17, 874-885. https://doi.org/10.15446/rsap.v17n6.49228 http://www.redalyc.org/comocitar.oa?id=42244105005

[9] Priscilla Valladares, B. and Márcia de Assunção, F. (2012) Equipe de enfermagem e comunicação: contribuições para o cuidado de enfermagem. Revista Brasileira de Enfermagem, 65, 97-103. https://doi.org/10.1590/S0034-71672012000100014

[10] Raquell Alves de, A., Hemília Gabrielly de Oliveira, C., Samira Maria Oliveira, A., Fátima Maria da Silva, A., Antonio José de, A.F. and Clara Maria Silvestre Monteiro de, F. (2012) Contribuições da filosofia para a pesquisa em enfermagem. Escola An na Nery, 16, 388-394. https://doi.org/10.1590/S1414-81452012000200025

[11] Freire da Silva, F., de Fátima da Silva, L. and Silva Rabelo, A. (2015) Processo de enfermagem no conforto do paciente com insuficiência cardíaca no domicílio. Aquichan, 15, 116-128. https://doi.org/10.5294/aqui.2015.15.1.11

[12] Melo, H.C., Araújo, S.E.G., Veríssimo, A.V.R., Santos, V.E.F.A., Alves, E.R.P. and Souza, M.H.N. (2012) O ser-enfermeiro em face do cuidado à criança no pós-operatório imediato de cirurgia cardíaca. Escola Anna Nery, 16, 473-479. https://doi.org/10.1590/S1414-81452012000300007

[13] Bardin, L. (2009) Análise de conteúdo. Edições, Lisboa, 70.

[14] Reglamento de la Ley General de Salud en Materia de investigación para la Salud (2013). http://www.salud.gob.mx/unidades/legis/lgs/LEY_GENERAL_DE_SALUD.pdf

[15] Amorim, R.K.F.C.C. and Silva, M.J.P. (2014) Effective/Efficacious Nonverbal Communication in the Classroom: The Perception of the Nursing Lecturer. Texto \& Contexto-Enfermagem, 23, 862-870. https://doi.org/10.1590/0104-07072014001710013

[16] Schaurich, D., Oliveira Crossetti, M. and de Mello Padoin, S. (2011) Filosofia Buberiana e a produção da pós-graduação stricto sensu brasileira: Revisão integrativa. Revista Brasileira de Enfermagem, 64, 1132-1140. https://doi.org/10.1590/S0034-71672011000600022

[17] Oliveira, K.M.D., Abreu, A.K.D.C., Rodrigues, M.C.S. and Freitas, R.L.A. (2016) Relações dialógicas e assistência segura ao paciente: Reflexão à luz da filosofia buberiana. Cogitare Enferm, 21, 1-5. https://doi.org/10.5380/ce.v21i5.45264

[18] Aguilar-Idáñez and Buraschi (2017) Claves dialógicas para una educación intercultural crítico-transformadora. Revista Interdisciplinar da Mobilidade Humana REMHU, 38, 27-43.

http://www.csem.org.br/remhu/index.php/remhu/article/view/298 
[19] Díaz Renteria, M.G. (2013) Philosophy of Science Care Analogy of the Myth of Plato's Cave with the Nursing Profession. Revista Iberoamericana de las Ciencias de la Salud, 2, 156-162. https://doi.org/10.1111/2047-3095.12059

[20] Menossi, M., Cardeal da Costa Zorzo, J. and Garcia de Lima, R. (2012) A dialógica vida/morte no cuidado do adolescente com câncer. Revista Latino-Americana de Enfermagem, 20, Tela 1-Tela 9.

http://www.redalyc.org/articulo.oa?id=281421971017

[21] Martin, Y.C. and Pessoni, A. (2015) Comunicação e saúde na enfermagem: Um estudo bibliométrico. Revista Eletrônica de Comunicação, Informação \& Inovação em Saúde, 9, 1-13.

http://repositorio.uscs.edu.br/bitstream/123456789/660/2/445-2443-1-PB.pdf 